\title{
DEVELOPMENT OF CAUDAL FIN CELL LINE FROM HILL TROUT Barilius bendelisis (HAMILTON, 1807) FOR CYTOTOXICITY AND TRANSFECTION STUDIES
}

\author{
Murali Sanjeev Kumar, Pankaj Soni, Ravindra Kumar, Neha Singh, Shreya Srivastava, Akhilesh Kumar \\ Mishra, Vijay Kumar Singh, Basdeo Kushwaha*
}

ICAR-National Bureau of Fish Genetic Resources, Canal Ring Road, P.O. Dilkusha, Lucknow-226 002, India

*Corresponding Author: basdeo.scientist@gmail.com

\section{ARTICLE INFO}

Received: 13 August 2020

Accepted: 14 October 2020
Keywords:

Barilius bendelisis

Cell line

Heavy metal cytotoxicity

NRFC

How to Cite

\begin{abstract}
A cell line named BBdF-1, established from the caudal fin of hill stream fish Barilius bendelisis, has been subcultured for more than 52 passages and is being maintained in L-15 media containing 20\% FBS. Species origin of the cell line was confirmed using amplification of partial region of $16 \mathrm{~S}$ and $\mathrm{COI}$ mitochondrial gene sequences. The optimum temperature for growth of BBdF-1 cell line was found to be $28^{\circ} \mathrm{C}$. Karyotyping revealed diploid chromosome number as 50. Cells exhibited strong binding for cytokeratin marker and thus were found to be epithelial-like. Strong green fluorescence was observed in BBdF-1 cells transfected with phrGFP-II-N vector, indicating its suitability for utilization in gene expression and manipulation studies. Successful assessment of cytotoxicity of two heavy metals, viz. mercury and chromium, was performed. The cell line can serve as a useful resource material for early toxicity screening of pesticides/ pollutant and gene expression.
\end{abstract}

Kumar, M. S., Soni, P., Kumar, R., Singh, N., Srivastava, S., Mishra, A. K., Singh, V. K., Kushwaha, B. (2021): Development of caudal fin cell line from hill trout Barilius bendelisis (Hamilton, 1807) for cytotoxicity and transfection studies. Croatian Journal of Fisheries, 79, 15-24. DOI: 10.2478/ cjf-2021-0002. 


\section{INTRODUCTION}

Barilius bendelisis, a hill stream minor carp belonging to the Cyprinidae family, characterized by a compressed body with blackish-blue bars and distant dorsal fin from the middle point of the body, is found widely distributed in Asian countries, viz. India, Nepal, Bhutan, Sri Lanka, Myanmar, Bangladesh, etc. (Talwar and Jhingran, 1991; Oo, 2002; Sukham et al., 2013; Singh et al., 2016). It is popularly called hill trout or Hamilton's barila (Hamilton, 1822) and constitutes an important food and ornamental fishery in several Himalayan regions of Uttarakhand, Assam, Meghalaya, Manipur and Arunachal Pradesh of India where efforts of raising exotic or Indian major carps have not been successful (Mir et al., 2015; Sahoo et al., 2009; Mishra et al., 2012; Sharma et al., 2015). They are also an important part of small-scale capture fisheries in hilly regions of Odisha, Chhattisgarh, Madhya Pradesh, Telangana and Maharashtra states of India. The species in Bangladesh has been categorized as endangered (IUCN Bangladesh, 2010) even though in India, B. bendelisis is categorized as a "least concern" species, the unknown reasons for natural reduction of this species are a matter of concern and therefore its preservation as a genetic resource is of much importance (Mir et al., 2015; Vishwanath, 2010).

Establishment of a cell line is one of the tools to preserve DNA as means of ex situ conservation. In India, National Repository of Fish Cell lines (NRFC), the world's largest fish cell line repository at ICAR-National Bureau of Fish Genetic Resources, Lucknow, has been maintaining more than 70 fish cell lines and making them available ondemand for researchers (http://mail.nbfgr.res.in/nrfc/ celline.php). B. bendelisis have been reported to be well adapted to most environmental conditions and are potential aquaculture candidate species. Further they are easy to maintain in labs or aquarias (Dewan et al., 2016). The present study was aimed to establish and characterize a new cell line from hill trout $B$. bendelisis and to evaluate it for cytotoxicity and transfection studies. Further, the cell line was also evaluated for optimum growth conditions, cryopreservation potential, chromosome analysis, etc. This is the first cell line to be reported from this species with potential applications for many in vitro studies.

\section{MATERIALS AND METHODS}

\section{Preparation of tissue for primary culture}

The procedure for the development of primary culture was followed according to the standard operating procedures of NRFC laboratory (http://mail.nbfgr.res.in/ $\mathrm{nrfc} / \mathrm{sop} . \mathrm{php})$. In brief, "live specimens of around $20 \mathrm{~g}$ body weight of $B$. bendelisis were collected from the Kalsa stream, near Chafi, Uttarakhand, India and acclimatized for a week at $25^{\circ} \mathrm{C}$. A healthy specimen was allowed to swim in sterile water containing antibiotic-antimycotic solution (HiMedia cat\# A002-20ML taking 10X solution from the 100X) for an hour and anaesthetized using clove oil before use for the study. Then, after surface sterilization of the specimen using $70 \%$ ethanol, a piece of caudal fin was aseptically excised and washed thrice with phosphate buffer saline (PBS) containing $2 X$ concentration of antibiotic-antimycotic solution followed by a single wash with $1 \mathrm{ml}$ fresh PBS containing $1 \mathrm{X}$ of antibioticantimycotic solution (HiMedia cat\# A002-20ML). The fin tissue was minced into small pieces with the help of a sterile scalpel blade and transferred to a $25 \mathrm{~cm}^{2}$ flask and incubated at 25 and $28^{\circ} \mathrm{C} .100 \mu \mathrm{l}$ fetal bovine serum (FBS) was added in the culture flask after 4-6 hours for facilitating good attachment of explants. Then $5 \mathrm{ml}$ of Leibovitz's-15 (L-15) (HiMedia), supplemented with 20\% FBS containing $1 \mathrm{X}$ antibiotic and antimycotic solution, was added to the flask and incubated again. The culture flask was observed daily for cell growth and any contamination. Half of the media was changed at every 4 days interval till the formation of a full monolayer."

\section{Subculture and maintenance}

After complete monolayer formation, the cells were harvested and further subcultured, and passaged in the ratio of $1: 2$ using $30 \% 1 \mathrm{X}$ trypsin-EDTA solution diluted with PBS. The cells were passaged routinely.

\section{Cryopreservation and revival}

The cell line was cryopreserved after every five passages in liquid nitrogen $\left(\mathrm{LN}_{2}\right)$. When the tissue culture flask reached a confluency level of $70-80 \%$, cells were harvested and collected by trypsinization method. After washing with 2 $\mathrm{ml} \mathrm{PBS}$, the cells were re-suspended in a freezing medium (containing pre-cooled L-15 medium supplemented with FBS and dimethyl sulphoxide (DMSO)) as cryopreservative at 9:1 ratio. The cells were then transferred to $1.8 \mathrm{ml}$ cryovials at a density of $1 \times 10^{6}$ cells $/ \mathrm{ml}$ and stored at $-20^{\circ} \mathrm{C}$. After $4 \mathrm{~h}$, the cells were kept overnight at $-80^{\circ} \mathrm{C}$ and then transferred to liquid nitrogen $\left(\mathrm{LN}_{2}\right)$ vapour phase for cryopreservation. Cells were successfully revived after 6 months. The cryovials containing cells were taken out from $L N_{2}$, thawed quickly at $37^{\circ} \mathrm{C}$ in a water bath and re-suspended in $10 \mathrm{ml} \mathrm{L-15}$ complete media. Cells were pelletized at 1,000 rpm for $5 \mathrm{~min}$ at room temperature (RT), re-suspended again in $6 \mathrm{ml} \mathrm{L-15}$ complete media and seeded into $25 \mathrm{~cm}^{2}$ cell culture flask. For measuring cell viability, trypan blue staining was used. Live cells were counted using a hemocytometer under an inverted microscope.

\section{Growth studies}

To optimize growth conditions, the caudal fin cells were grown at different FBS concentrations and incubation temperatures, keeping one of the factors constant. The cells were trypsinized at 28 passage number, counted and then seeded into $25 \mathrm{~cm}^{2}$ flasks at $1 \times 10^{5}$ cells per flask and incubated at $28^{\circ} \mathrm{C}$ overnight for cell attachment. Next day, 
the old medium was replaced with fresh L-15 complete medium supplemented with 5, 10, 15 and 20\% FBS concentrations and the flasks were incubated at $28^{\circ} \mathrm{C}$ in triplicate. Each day, three flasks of each FBS concentration were trypsinized and counted using a hemocytometer. A similar procedure was followed with cells at passage level 30 to study the effect of selected temperatures (i.e. 24, 28,32 and $37^{\circ} \mathrm{C}$ ) on cell growth.

\section{Confirmation of origin of cell line by PCR}

Though traditional taxonomic keys were used to identify the fish specimen, the cells were also used to confirm the source species, through amplification and sequencing of partial region of mitochondrial genes using a pair of primers specific to two universal barcoding regions, i.e. 16S rRNA and $\mathrm{COI}$ genes. Partial amplification of genes was done at 30 passage level. DNA from the cells was isolated using Purelink Genomic DNA mini kit (Invitrogen, USA). "The primers used for 16S were: 5'-CGCCT GTTTATCAAAAACAT-3' (L), 5' $\quad$-CCGGTCTGAACTCAGATCACGT-3' (Palumbi et al., 1991) and for COI were: 5'-TCAACCAACCACAAAGACATTGGCAC-3' (forward), 5'-TAGACT TCTGGGTGGCCAAAGAATCA-3' (reverse) (Ward et al., 2005)". The amplified products were analyzed at $1.5 \%$ agarose gels, stained with ethidium bromide and visualized with ultraviolet transilluminator, to confirm the size. The amplicons were sequenced on 3730xI DNA Analyzer (Applied Biosystems, USA) and were aligned against known sequences from the NCBI database.

\section{Chromosome analysis}

The caudal fin cells grown till $70-80 \%$ confluence were trypsinized and retained in the same $75 \mathrm{~cm}^{2}$ size culture flask and were allowed to grow overnight for increasing the number of dividing cells. Next day, $25 \mu$ l colchicine $(0.05 \%$ conc.) was added to the culture media of the flask and incubated at $28^{\circ} \mathrm{C}$ for $2 \mathrm{~h}$. Afterwards, cells were trypsinized, collected in a tube and incubated with $5 \mathrm{ml}$ hypotonic solution $(0.56 \% \mathrm{KCl})$ for $20 \mathrm{~min}$ at $37^{\circ} \mathrm{C}$. After hypotonic treatment, $1 \mathrm{ml}$ chilled Carnoy's fixative (3:1 methanol and acetic acid) was added to the tube and cells were pelletized by centrifugation at 1,200 rpm for $10 \mathrm{~min}$. The supernatant was then discarded leaving $1 \mathrm{ml}$ solution with cell pellet, which was re-suspended in the remaining $1 \mathrm{ml}$ solution followed by addition of $4 \mathrm{ml}$ fresh fixative slowly for cell fixation. The same process was repeated 3-4 times for proper cell fixation. The chromosome preparation was made by conventional splash drop technique (Freshney, 2005). The number of chromosomes in each spread was counted under a light microscope (Leica DMLB-2). A total of 30 spreads were counted.

\section{Confirmation of cell morphology}

The cells were grown on a sterile coverslip and incubated overnight at $28^{\circ} \mathrm{C}$ for attachment. Next day, the cells were washed twice with PBS followed by cell fixation and permeabilization with 1:1 methanol-acetone solution for
$20 \mathrm{~min}$ at $-20^{\circ} \mathrm{C}$ and then incubated with $3 \%$ BSA in PBS ( $3 \% \mathrm{P}-\mathrm{BSA})$ solution for $1 \mathrm{~h}$ at $37^{\circ} \mathrm{C}$. After $1 \mathrm{~h}$, the cells were washed twice with PBS and incubated overnight at $4^{\circ} \mathrm{C}$ with primary antibodies [mouse anti-cytokeratin pan (Sigma), anti-fibronectin (Sigma) and mouse anti-vimentin antibodies] diluted in 1\% PBSA. For control, 1\% PBSA without primary antibodies was used. Cells were then washed with $\mathrm{PBS}$ and incubated at $37^{\circ} \mathrm{C}$ for $1 \mathrm{~h}$ with rabbit anti-mouse IgG FITC conjugate (diluted 1:100 in PBSA). Finally, the coverslip was washed again with PBS, mounted in 1:1 of PBS \& glycerol and checked for fluorescence.

\section{Plating efficiency and doubling time}

Doubling time and plating efficiency were calculated as described by Freshney (2005). Plating efficiency, also known as clonogenic assay or colony-forming assay, was determined at 33 passage level. Briefly, cells were trypsinized, counted and seeded into $25 \mathrm{~cm}^{2}$ culture flasks at a density of 100, 500 and 1,000 cells per flask in triplicates. L-15 medium supplemented with $20 \%$ FBS was used to culture the seeded cells at $28^{\circ} \mathrm{C}$ for the study. On every $4^{\text {th }}$ day, half of the medium was changed. After 12 days, flasks were decanted, cells washed with PBS, fixed using methanol and stained with crystal violet. The individual cell colonies were then counted under an inverted microscope. The population doubling time of the cell line was calculated at two passages, 32 and 40.

\section{Mycoplasma detection}

The cell line was checked for mycoplasma contamination using a PCR-based test. Cells were subcultured at passage level 35 in L-15 complete medium, containing 20\% FBS without antibiotics, for 5 days. Afterwards, $2 \mathrm{ml}$ of the supernatant from the flask was collected and centrifuged at 13,000 rpm for $30 \mathrm{~min}$. Obtained pellet was dissolved in $50 \mu$ of $1 \times$ TE buffer, then vortexed and heated for 10 min at $95^{\circ} \mathrm{C}$. The EZdetectTM PCR kit (HiMedia, India) for mycoplasma detection was used as per the manufacturer's protocol using positive control (as provided in the kit), negative control (where no DNA template used) and cell supernatant. For this, amplification of the region between 165 and 235 rRNA was carried out, and the amplified products were electrophoresed at $2 \%$ agarose gel and visualized under UV transilluminator.

\section{Cytotoxicity assays}

The cytotoxicity of two salts of heavy metals, mercuric chloride $\left(\mathrm{HgCl}_{2}\right)$ and potassium dichromate $\left(\mathrm{K}_{2} \mathrm{Cr}_{2} \mathrm{O}_{7}\right)$, was evaluated using the cell line through alamarBlue assay. Briefly, $3 \times 10^{4}$ cells per $\mathrm{ml}$ in $100 \mu \mathrm{L}$ of $\mathrm{L}-15$ medium supplemented with $20 \%$ FBS were seeded in 96 well plates and incubated overnight at $28^{\circ} \mathrm{C}$. The culture medium was then discarded and $100 \mu \mathrm{L}$ of L-15 containing different concentrations $(3000,1500,750,375,187.5,93.75$, $46.87,23.43,11.71 \mu \mathrm{M}$ ) of analytical grade $\mathrm{HgCl}_{2}$ (SigmaAldrich, USA) was added to the wells in triplicates and incubated at $28^{\circ} \mathrm{C}$. Toxicant concentration was prepared 
in L-15 supplemented with $4 \% \mathrm{FBS}$. In control, the cells present in the wells were incubated only with $100 \mu \mathrm{L}$ of L-15 medium. After $24 \mathrm{~h}, 10 \mathrm{ul}$ alamarBlue reagent was added to the wells and incubated for $2 \mathrm{~h}$. Then, light absorption was measured at 2 wavelengths, 570 and $600 \mathrm{~nm}$, using a spectrophotometer (Synergy, BioTek Instruments, Winooski, VT, USA) and their respective readings were recorded. Similar methodology was also used for analytical grade $\mathrm{K}_{2} \mathrm{Cr}_{2} \mathrm{O}_{7}$ (Sigma-Aldrich, USA), where concentrations ranged from 1000 to $3.9 \mu \mathrm{M}$. The recorded absorption readings were then subjected to dose-response curve fitting using GraphPad Prism 6 Software and $\mathrm{IC}_{50}$ value was calculated.

\section{Transfection}

The caudal fin cells at 51 passage level were seeded into 6 well plates and incubated overnight at $28^{\circ} \mathrm{C}$ for attachment. Sub-confluent monolayers of cells were transfected with $1.5 \mu \mathrm{g}$ of phrGFP-II-N vector (Clontech, Takara Bio USA, Inc.), using lipofectamine 2000 (Invitrogen, Carlsbad, USA). After $48 \mathrm{~h}$, the 6 well plates were observed under a Nikon fluorescence microscope.

\section{RESULTS}

\section{Primary cell culture and subculture}

While the radiation of cells from the fin tissues of $B$. bendelisis was observed on the $4^{\text {th }}$ day of setting of explants, good radiation from most of the explants was noticed only after 7 days.

Formation of a complete monolayer of cells took around 20-25 days, after which they were harvested and subcultured every 5-6 days at a ratio of 1:2. The morphology of the subcultured cells didn't change after many successive passages and seemed stable. As the flasks started getting confluent very fast, the percentage of FBS concentration was reduced to $15 \%$ after the $35^{\text {th }}$ passage. The cell line was subcultured until 52 passages over a period of one year and designated as BBdF-1 (Fig. $1 \mathrm{~A}, \mathrm{~B})$.

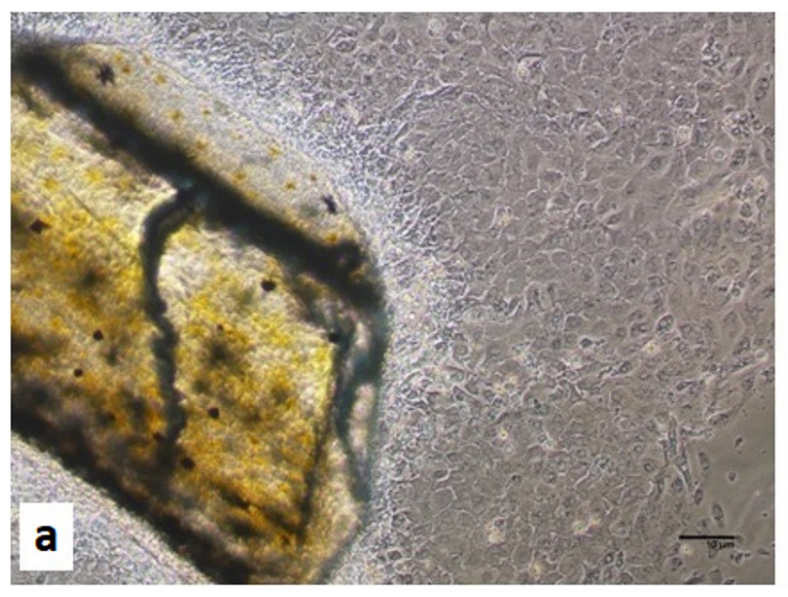

Fig 1. Image of $B$. bendelisis cells derived from fin tissue: (a) primary culture on the $5^{\text {th }}$ day after tissue explant, (b) monolayer of cells at 25 passage

\section{Growth studies}

Fin cells of $B$. bendelisis showed different growth at different culture temperatures, viz. $24,28,32$ and $37^{\circ} \mathrm{C}$. The maximum growth rate was obtained at $28^{\circ} \mathrm{C}$, while the cell growth was modest at 24 as well as $32^{\circ} \mathrm{C}$ but lowest at $37^{\circ} \mathrm{C}$. The growth rate of cells at $28^{\circ} \mathrm{C}$ temperature increased as the FBS concentration increased from $5 \%$ to $20 \%$. At $5 \%$ FBS concentration, the cell growth was lowest but the cells were healthy. Although the cells grew well at $10 \%$ and $15 \%$ FBS concentration, the maximum growth was observed with $20 \%$ FBS concentration (Fig. 2A, B).

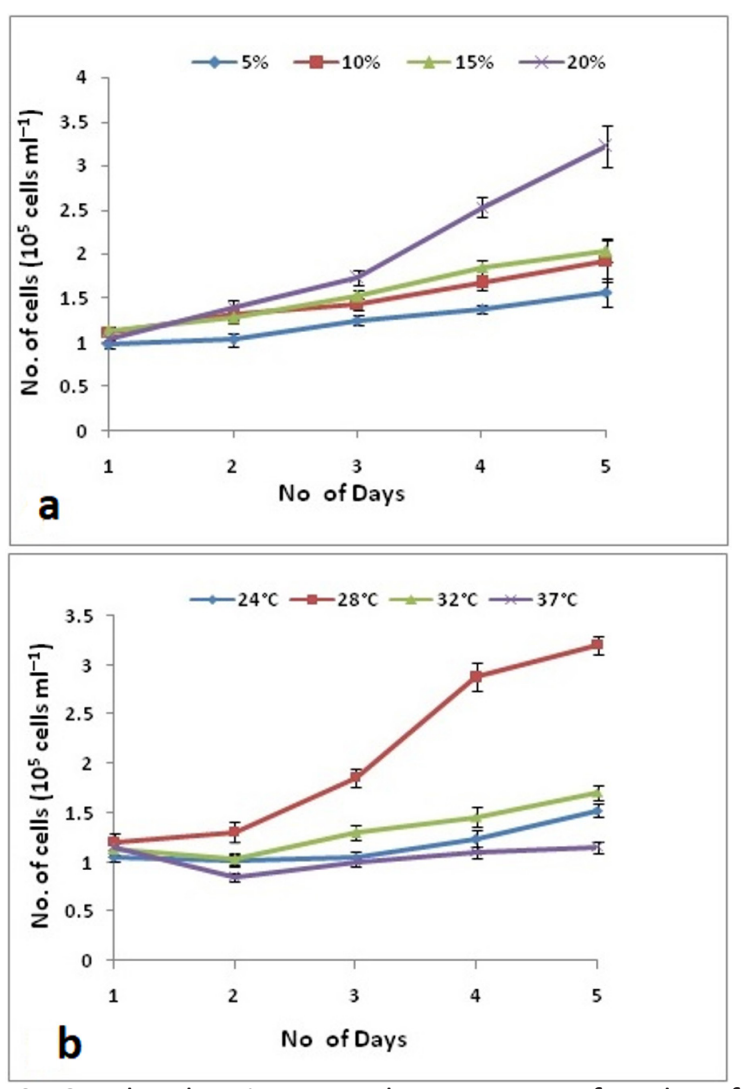

Fig 2. Graphs showing growth responses of BBdF-1 for various: (a) fetal bovine serum concentrations, and (b) culture temperatures

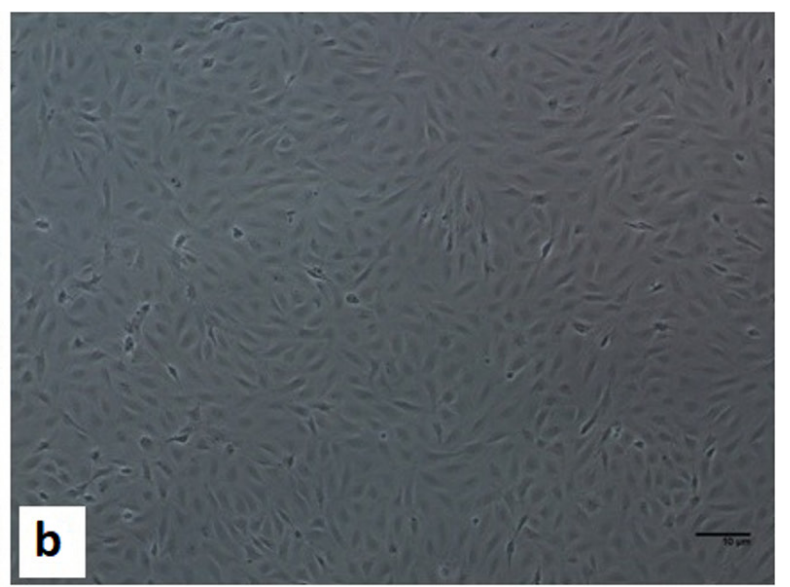




\section{Cryopreservation}

The BBdF-1 cells were cryopreserved successfully and revived with $75 \pm 4.98 \%$ viability after 4 months of storage in $\mathrm{LN}_{2}$. The cells grew well and reached confluence within 6 days in L-15 media containing 20\% FBS after revival.

\section{Confirmation of cell origin}

To confirm the origin of the cell line, partial regions of 16S rRNA and COI mitochondrial genes were amplified using template DNA of BBdF-1 cells. Partial COI gene has been submitted to NCBI GenBank database (Accession no: MN539107). The sequenced regions were blasted against available sequences in NCBI database, and the similarity for $16 \mathrm{~S}$ rRNA and $\mathrm{COI}$ regions of these were found to be 96.49 and $100 \%$, respectively, against known B. bendelisis.

\section{Chromosome analysis}

Chromosome counts of 30 metaphase spreads from BBdF-1 cells at 28 passage level revealed the variation in diploid chromosome numbers from 40 to 58 . However, the majority of the BBdF-1 cells showed 50 as a model diploid chromosome number in metaphase spreads (Fig. 3).

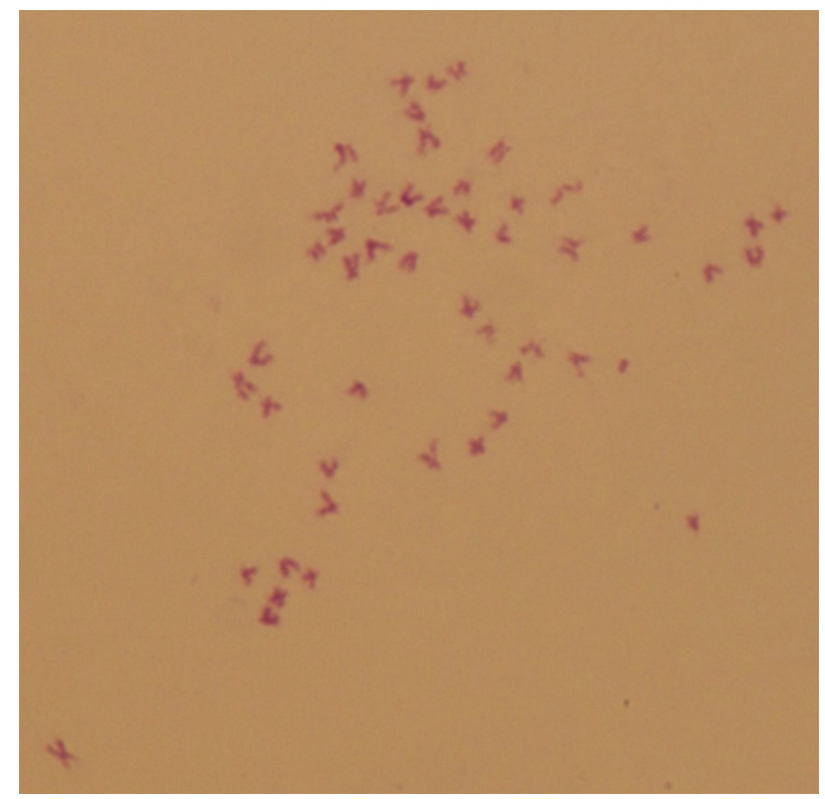

Fig 3. Metaphase chromosome complement of BBdF-1 cells

\section{Plating efficiency and doubling time}

The BBdF-1 cells seeded at a density of 100, 500 and 1000 cells per flask showed 5.3, 6.5 and $8.06 \%$ plating efficiency, respectively. The plating efficiency improved with an increase in the seeding density. Doubling time of the BBdF-1 cell line was found to be $68 \mathrm{~h}$ in L-15 medium supplemented with $20 \%$ FBS.

\section{Mycoplasma detection}

BBdF-1 cells were found to be free from mycoplasma contamination (Fig. 4).

\section{M \\ 12

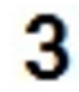

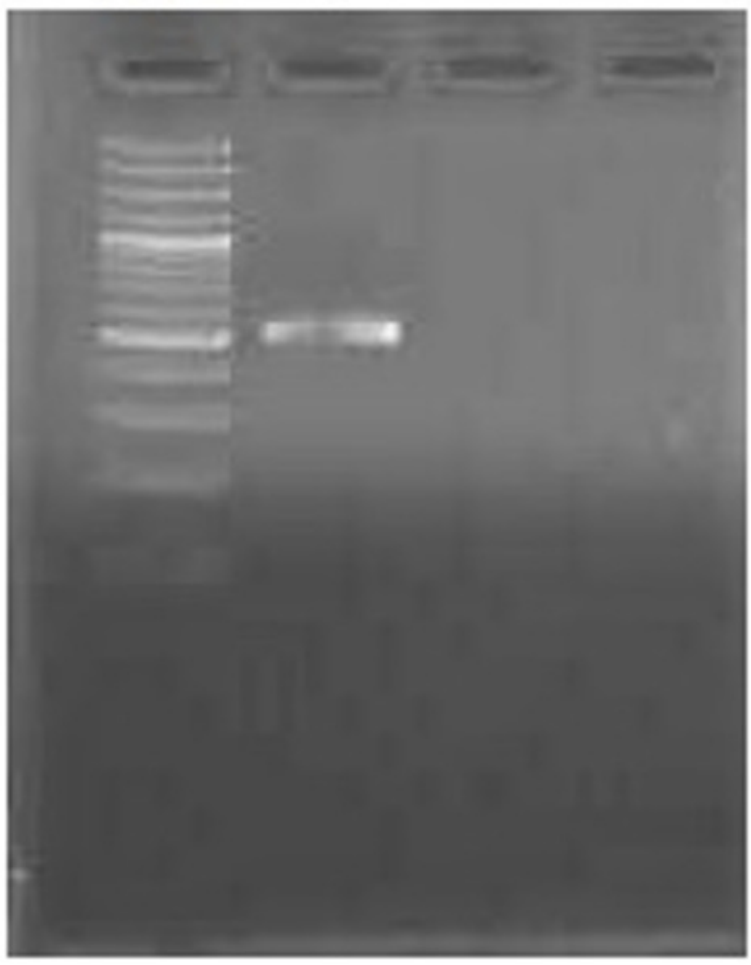

Fig 4. Gel image showing PCR product for mycoplasma detection (Lane M: 100 bp DNA ladder, Lane 1: positive control, Lane 2: negative control, and Lane 3: BBdf-1 cell supernatant)

\section{Transfection}

The BBdF-1 cell line was successfully transfected with lipofectamine 2000 transfection using phrGFP-II-N plasmid. Green fluorescence was observed after $48 \mathrm{~h}$ of transfection, which indicated the expression of green fluorescent protein (GFP) reporter in BBdF-1 cell line. The result suggests the suitability of the BBdF-1 cell line for gene expression studies (Fig. 5).

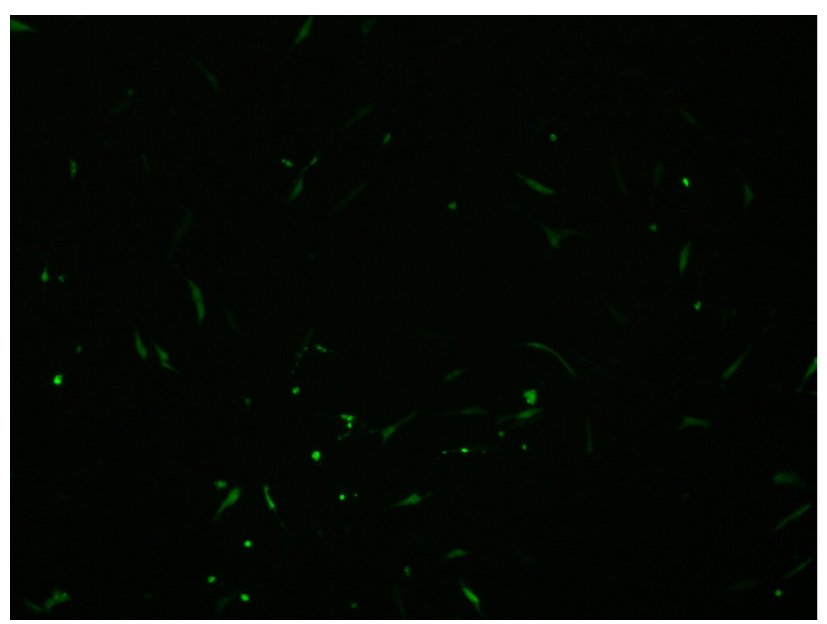

Fig 5. Expression of GFP gene in BBdF-1 cell line at 51 passage level 


\section{Cell type}

In cell type determination of BBdF-1 cells by immunophenotyping using antibody markers, strong positive green fluorescence signals for anti-cytokeratin pan antibody was recorded while no signals were observed in control anti-fibronectin and anti-vimentin antibodies, which indicated epithelial-like cell type (Fig. 6).

\section{Cytotoxicity studies}

The BBdF-1 cells were tested for their applicability for cytotoxicity evaluation. A decrease in absorbance was recorded with increasing concentration of both metal salts. The observed $\mathrm{IC}_{50}$ values were $190.2 \mu \mathrm{M}$ (139.2259.9) for $\mathrm{HgCl}_{2}$ and $56.48 \mu \mathrm{M}$ (43.7-73.01) for $\mathrm{K}_{2} \mathrm{Cr}_{2} \mathrm{O}_{7}$ using alamarBlue assay (Fig. 7).

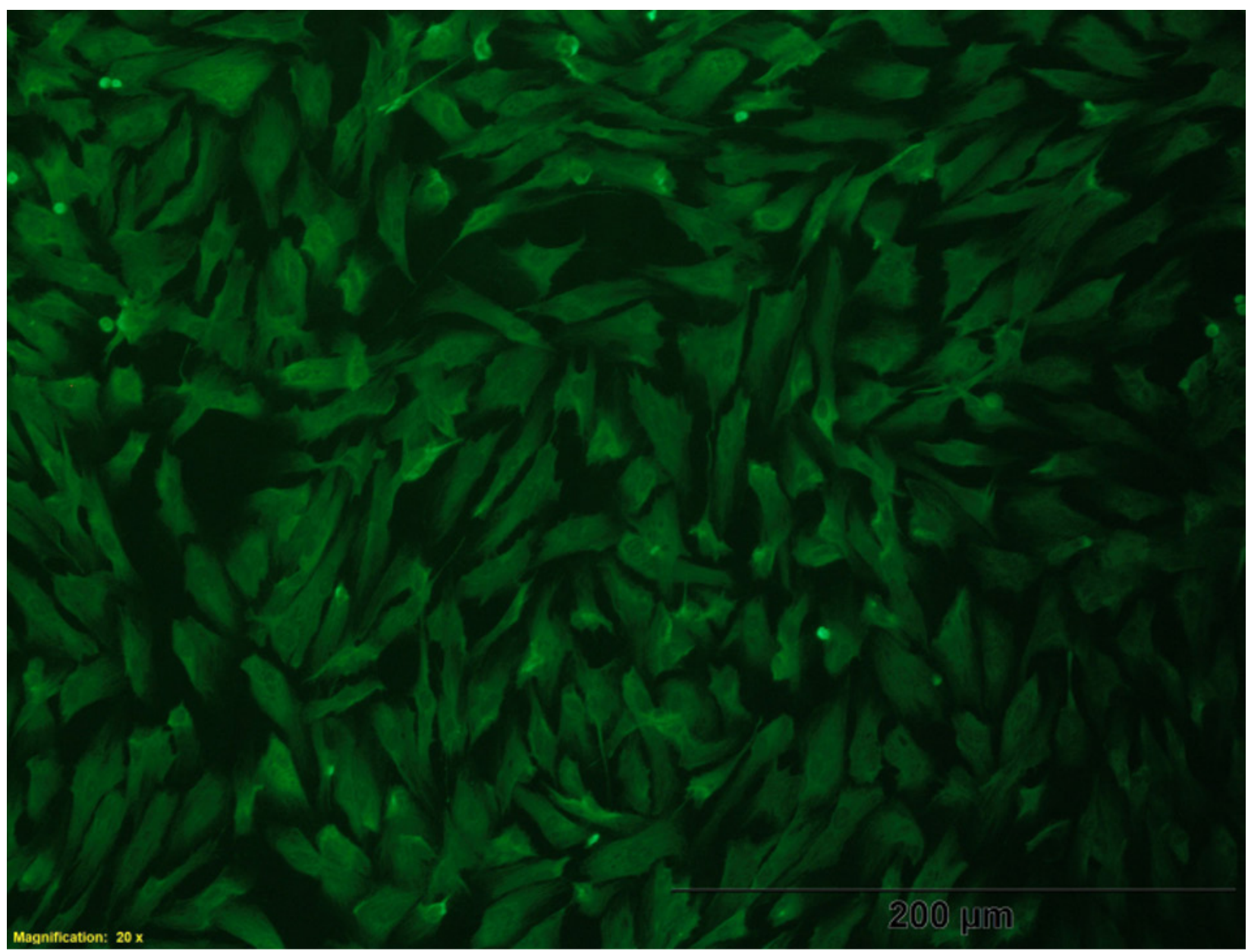

Fig 6. Fluorescent photomicrographs showing the presence of cytokeratin marker in BBdF-1 cells at) 20x Magnification
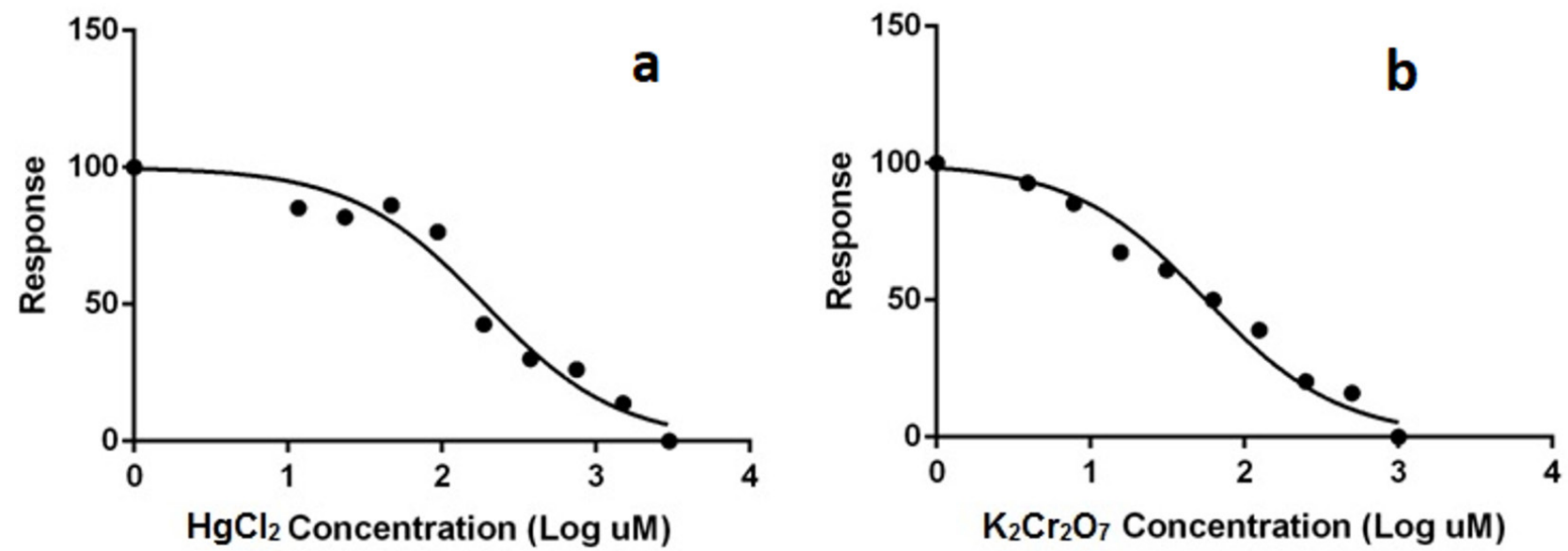

Fig 7. Viability of BBdF-1 cells after $24 \mathrm{~h}$ exposure to different test concentrations of $\mathrm{HgCl}_{2}$ and $\mathrm{K}_{2} \mathrm{Cr}_{2} \mathrm{O}_{7}$ using alamarBlue assay 


\section{DISCUSSION}

Cell lines from different organs, viz. gill, kidney, spleen, eye, muscle, swim bladder, skin, liver, etc., of different fish species have been established. Cellosaurus, a bioinformatics portal on cell line lists 714 fish cell lines (https://web.expasy.org/cgi-bin/cellosaurus/search). This phenomenal number of fish cell line development is because of growing applications of fish cell lines in toxicology, gene expression studies, developmental biology, biomedical research, etc. (Hightower and Renfro, 1988; Ryan et al., 2008; Lakra et al., 2011).

In the present study, a new fish cell line has been established from the caudal fin of $B$. bendelisis using explant method and designated as 'BBdF-1'. Explant method for primary culture is preferred over enzymatic method due to its ease, rapidity to avoid cell damage and has already been proven to be more suitable for many species as reported by various other researchers (Avella et al., 1994; Lakra et al., 2010; Chaudhary et al., 2014; Soni et al., 2018). The suitable temperature range for BBdF-1 cells was $24-32^{\circ} \mathrm{C}$ with optimum growth at $28^{\circ} \mathrm{C}$, which has also been reported by many researchers (Tong et al., 1997; Ku et al., 2009; Lakra et al., 2011) for several cell lines. The cells were barely surviving at $37^{\circ} \mathrm{C}$ and showed almost negligible growth, probably because the habitat of this species is hilly and low-lying regions where temperatures do not reach this limit. Likewise, the optimum serum concentration (i.e. FBS) was found to be $20 \%$ in $\mathrm{L}-15$ medium. For long term culture and experiments, 5\% FBS containing L-15 medium is not recommended for BBdF-1 cells due to comparatively lower growth rate. Cells also grew at $10 \%$ FBS in L-15 medium indicating that BBdF1 cells could also be maintained in L-15 medium ( $10 \%$ FBS) to reduce the operating cost and the probability of contamination due to high serum content. Further, the culture of BBdF-1 cells is cost-effective as they are grown in $\mathrm{L}-15$ and there is no requirement of expensive $\mathrm{CO}_{2}$ incubators. They can easily be grown in normal BOD incubators, unlike human and popular animal cell lines.

The average doubling time of $68 \mathrm{~h}$, reported for BBdF-1 cells at different passages, is higher than Schizothorax richardsonii (48 h, Goswami et al., 2013), Scophthalmus maximus (45.6 h, Fan et al., 2010), Channa striata (29 h, Majeed et al., 2015) but the cell line exhibits slow and stable growth rate. Plating efficiency, determined as around $8 \%$ for 1000 cells per flask for BBdF-1, though not very high, exhibits an increase in efficiency with increasing seeding density resulting in better cell growth. There are several other reports on various fish cell lines with low plating efficiencies (Swaminathan et al., 2012; Ma et al., 2013; Rodriguez et al., 2014).

It was possible to successfully subculture BBdF-1 cells for more than 50 passages in a period of 7 months. With increasing passages, cultured cells may attain some genotypic or phenotypic changes. Moreover, risk of culture loss is always there due to contamination and/or natural death of cells. To save the culture, cryopreservation is of much importance. BBdF-1 cells were cryopreserved at different passages and revived successfully with no morphological alternations. Maximum cell viability revived cells after cryopreservation was found to be $75 \pm 4.98 \%$ for BBdF-1 cells, whereas other researchers have reported $80-85 \%$ (Goswami et al., 2013), 90-92\% (Majeed et al., 2015), etc.

Different molecular markers are used to confirm the origin of cells. Partial 16S rRNA and COI genes have largely been employed for species characterization and phylogenetic analysis of many different species including fish and have proved to be an effective barcoding marker (Masuda et al., 1990; Marshall, 2005; Singh et al., 2016; Lakra et al., 2016). These two genes helped authenticate the origin of BBdF1 cells from $B$. bendelisis. Diploid model chromosome number of 50 further authenticated its origin from the same species, as also documented in other studies (Sukham et al., 2013). Different cell markers are used to confirm the types of cells. Strong fluorescence observed for cytokeratin antibodies revealed the epithelial-like type of the BBdF-1 cell line. Such fluorescence-based antibody marker tests were also used by other researchers with similar results (Revest et al., 2001; Gjessing et al., 2018; Soni et al., 2018).

BBdF-1 cells transfected with the GFP gene showed green fluorescent signals after $48 \mathrm{~h}$. Although the transfection efficiency was not calculated using flow cytometry, it was estimated to be $8-9 \%$ based on spot counting, which indicates that the BBdF-1 cells can also play a pivotal role in gene manipulation studies in this omics era.

Cytotoxicity testing using in vitro approach is one of the most important aspects at the current time. Fish cell lines have been used and are also continuously being employed for toxicity studies because fish are in direct contact with many eco-toxicants (Babich and Borenfreund, 1987). Moreover, reproducibility of results, ease and no requirement of animal killing make in vitro studies more suitable. In the present study, the $\mathrm{IC}_{50}$ values for BBdF1 cells exposed against $\mathrm{HgCl}_{2}$ were higher $(190.2 \mu \mathrm{M})$ than $\mathrm{K}_{2} \mathrm{Cr}_{2} \mathrm{O}_{7}(56.48 \mu \mathrm{M})$, which shows that chromium is more toxic than mercury (Tchounwou et al., 2012; Bakshi and Panigrahi, 2018). A gradual decrease in absorbance was recorded as per increase in toxicant concentration. Similar results were also obtained by different researchers for mercury (Sood et al., 2015; Tong et al., 2016) and chromium (Tan et al., 2010; Di et al., 2017). The B. bendelisis cell line has been deposited at NRFC at ICARNBFGR, Lucknow, Uttar Pradesh (India) (NRFC Accession no: NRF(061), thus making it available to researchers globally for R\&D work. 


\section{CONCLUSION}

Hill streams harbor wide biological diversity and are also natural habitat of a large number of fish species. They also play an important role in maintaining ecological balance. As very few cell lines from cold water and hill stream fishes are available, $B$. bendelisis cell line BBdF1 has been developed and characterized using several standard parameters. This cell line has proved to be useful for various studies, viz. toxicological and gene transfection studies. This cell line can also be a beneficial source for virus isolation not only in this species but also for other hill stream fishes if any viral disease is reported. The developed cell line thus can lead researchers to expand further their experimental insights for investigating disease outbreaks, environmental pollutant monitoring and other studies.

\section{ACKNOWLEDGEMENT}

The authors are thankful to the Director, ICAR-NBFGR, Lucknow, for support and providing the necessary facilities to carry out this work. The authors are also thankful to the Department of Biotechnology, Government of India, New Delhi, India for providing the financial support of the work vide Sanction Order No. BT/PR13908/AAQ/3/733/2015.

\section{RAZVOJ STANIČNE LINIJE REPNE PERAJE IZ BRDSKE ŠARANKE, Barilius bendelisis (HAM- ILTON, 1807), ZA STUDIJE CITOTOKSIČNOSTI I TRANSFEKCIJE}

\section{SAŽETAK}

Stanična linija, nazvana BBdF-1, uspostavljena iz repne peraje Barilius bendelisis, presađena je na više od 52 "oblika“(prolaza) a održavala se u medijima L-15 koji sadrže $20 \%$ FBS. Porijeklo stanične linije potvrđeno je pomoću pojačanja djelomičnog područja $16 \mathrm{~S}$ i COI mitohondrijskih genskih sekvenci. Utvrđeno je da je optimalna temperatura za rast stanične linije BBdF- $128^{\circ} \mathrm{C}$. Kariotipizacijom se utvrdio diploidni broj kromosoma kao 50. Stanice su pokazale snažno vezanje za citokeratinski marker i, prema tome, utvrđeno je da sliče epitelu. Jaka zelena fluorescencija primijećena je u stanicama BBdF1 transficiranim vektorom phrGFP-II-N, što ukazuje da je prikladna za upotrebu u ispitivanjima ekspresije i manipulacije gena. Izvršena je i uspješna procjena citotoksičnosti dvaju teških metala, žive i kroma. Stanična linija može poslužiti kao koristan izvorni materijal za ranu provjeru toksičnosti pesticida/zagađivača i ekspresije gena.

Ključne riječi: Barilius bendelisis, stanična linija, citotoksičnost metala, NRFC

\section{REFERENCES}

Avella, M., Berhaut, J., Payan, P. (1994): Primary culture of gill epithelial cells from the sea bass Dicentrarchus labrux. In Vitro Cell Dev Biol Anim, 30, 41-49.

Babich, H., Borenfreund, E. (1987): Cultured fish cells for the ecotoxicity testing of aquatic pollutants. Toxicity Assessment, 2, 2, 119-33.

Bakshi, A., Panigrahi, A. K. (2018): A comprehensive review on chromium induced alterations in fresh water Fishes. Toxicol Rep, 5, 440-447.

Chaudhary, D. K., Sood, N., Rathore, G., Pradhan, P. K., Punia, P., Agarwal, N. K., Jena, J. K. (2014): Establishment and characterization of macrophage cell line from thymus of Catla catla (Hamilton, 1822). Aquacult Res, 45, 299-311.

Dewan, S., Singh, Y., Bhatt, J. P. (2016): Proteome adjustments post gradual hypoxic stress in Barilius bendelisis: insights into adaptive strategies of a hill stream cyprinid. Current Proteomics, 13, 1, 20-30.

Di, W., Xia, L., Yanjie, Q., Liwen, B., Shijia, Z. (2017): Toxic effects of potassium dichromate on loach fin cell lines with different ploidies in vitro. J Fish China, 24, 1, 173179.

Fan, T. J., Ren, B. X., Geng, X. F., Yu, Q. T., Wang, L. Y. (2010): Establishment of a turbot fin cell line and its susceptibility to turbot reddish body iridovirus. Cytotechnology, 62, 3, 217-223.

Freshney, R. I. (2005): Culture of Animal Cells - A Manual of Basic Techniques. Wiley-Liss, New York, NY, USA, pp. 641.

Gjessing, M. C., Aamelfot, M., Batts, W. N., Benestad, S. L., Dale, O. B., Thoen, E. (2018): Development and characterization of two cell lines from gills of Atlantic salmon. Plos One, 13, 2: e0191792.

Goswami, M., Sharma, B. S., Bahugun, S. N., Nagpure, N. S., Lakra, W. S. (2013): A SRCF cell line from snowtrout, Schizothorax richardsonii: Development and Characterization. Tissue Cell, 45, 219- 226.

Hamilton, F. (1822): An account of the fishes found in the river Ganges and its branches. Printed for a constable and company, Edinburgh \& London, pp 405.

Hightower, L. H., Renfro, J. L. (1988): Recent applications of fish cell culture to biomedical research. J Exp Zool, 248, 290-302.

IUCN Bangladesh (2010): Red book of threatened species of Bangladesh. IUCN-The world conservation union. Xii+, 116.

Ku, C. C., Teng, Y. C., Wang, C. S., Lu, C. H. (2009): Establishment and characterization of three cell lines derived from the rockfish grouper Epinephelus quoyanus: use for transgenic studies and cytotoxicity testing. Aquac, 294, 147-151.

Lakra, W. S., Goswami, M., Swaminathan, T. R., Rathore, G. (2010): Development and characterization of two new cell lines from common carp, Cyprinus carpio (Linn). Biol Res, 43, 385-392. 
Lakra, W. S., Singh, Goswami, M., Gopalakrishnan, A., Lal, K. K., Mohindra, V., Sarkar, U. K., Punia, P., Singh, K.

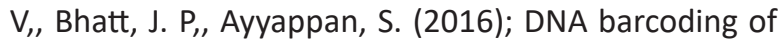
Indian freshwater fishes. Mitochondrial DNA A, 27, 6, 4510-4517.

Lakra, W. S., Swaminathan, T. R., Joy, K. P. (2011): Development, characterization, conservation and storage of fish cell lines: a review. Fish Physiol Biochem, 37, 1-20.

Ma, J., Sun, S., Zeng, L., Lu, Y. (2013): Establishment, characterization and viral susceptibility of two cell lines derived from leopard wrasse Macropharyngodon geoffroy. J Fish Biol, 83, 3, 560-573.

Majeed, S. A., Nambi, K. S., Taju, G., Hameed, A. S. (2015): Isolation, propagation, characterization, cryopreservation, and application of novel cardiovascular endothelial cell line from Channa striatus (Bloch, 1793). Cell Biochem Biophys 1, 71, 2, 601-16.

Marshall, E. (2005): Will DNA bar codes breathe life into classification? Science, 307, 1037.

Masuda, A., Ohtsuka, K., Matsuyama, M. (1990): Establishment of functional epithelial cell lines from a rat thymoma and a rat thymus. In Vitro Cell Dev Biol Anim, 26, 713-721.

Mir, J. I., Patiyal, R. S., Sharma, N. K. (2015): Analysis of length-weight relationship of sympatric hill stream teleosts Barilius bendelisis (Hamilton, 1807) and Barilius vagra (Hamilton, 1822) from Garhwal Himalaya, India. J Appl Ichthyol, 31, 4, 771-772.

Mishra, AK, Lakra W. S., Bhatt, J. P., Goswami, M., Nagpure, N. S. (2012): Genetic characterization of two hill stream fish species Barilius bendelisis (Ham.1807) and Barilius barna (Ham.1822) using RAPD markers. Mol Biol Rep, 39, 10167-10172.

Oo, W. (2002) Inland fisheries of the Union of Myanmar. In: Petr T, Swar DB (Eds.), Cold Water Fisheries in the Trans-Himalayan Countries. FAO Fisheries Technical Paper 431. http://www.fao.org/3/y3994e/y3994e09. htm

Palumbi, S., Martin, A., Romano, S., McMillan, W. O., Stice, L., Grabowski, G. (1991): The Simple Fool's Guide to PCR. University of Hawaii, Honolulu, HI, USA. https:// palumbilab.stanford.edu/SimpleFoolsMaster.pdf

Revest, J. M., Ravinder, Suniara, K., Kerr, K., John, Owen., J. J., Dickson, C. (2001): Development of the thymus requires signaling through the fibroblast growth factor receptor R2-IIIb. J Immunol, 167, 4, 1954-1961.

Rodriguez, S. J. S., Gonzalez, C., Monras, M., Romero, A., Ballesteros, N., Enriquez, R., Perez-Prieto, S. (2014): Establishment and characterization of a new cell line SSP-9 derived from Atlantic salmon Salmo salar that expresses type I ifn. J Fish Biol, 85, 1526-1545.

Ryan, L. A., Seymour, C. B., Mehlenbacher, ONA., Mothersill, C. E. (2008): Radiation-induced adaptive response in fish cell lines. J Environ Radioact, 99, 739747.
Sahoo, P. K., Saikia, S. K., Das. D. K. (2009): Natural food resources and niche breadth of Barilius bendelisis (Hamilton) (Pisces, Cyprinidae) in river Dikrong, an upland riverine ecosystem in India. Pan-Am j aquat, 4, 1, 12-16.

Sharma, N. K., Akhtar, M. S., Pandey, N., Singh, R., Singh, A. K. (2015): Seasonal variation in thermal tolerance, oxygen consumption, antioxidative enzymes and nonspecific immune indices of Indian hill trout, Barilius bendelisis (Hamilton, 1807) from central Himalaya. India. J Therm Biol, 52166-52176.

Singh, A. K., Kumara, R., Mishra, A. K, Singh, M., Baisvar, V. S., Chauhan, U. K., Kushwaha, B., Nagpure, N. S. (2016): Authentication of five Barilius species from Indian waters using DNA barcoding. Russ J Genet, 52, 8, 840846.

Soni, P., Pradhan, P. K., Swaminathan, T. R., Sood, N. (2018): Development, characterization and application of a new epithelial cell line from caudal fin of Pangasianodon hypophthalmus (Sauvage 1878) Acta Trop, 182, 215-222.

Sood, N., Chaudhary, D. K., Pradhan, P. K., Verma, D. K., Swaminathan, T. R., Kushwaha B., Punia, P., Jena, J. K. (2015): Establishment and characterization of a continuous cell line from thymus of striped snakehead, Channa striatus (Bloch 1793) In Vitro Cell Dev Biol Anim, 51, 8, 787-796.

Sukham, M. S., Chingakham, B., Thoidingjam, L., Waikhom, G., Kumar, R., Kushwaha, B. (2013): A note on karyotype structure in Barilius bendelisis (Hamilton, 1807) (Cypriniformes: Cyprinidae) from Northeast India. Int J Fish Aquac, 3, 3, 42-46.

Swaminathan, T. R., Lakra, W.S., Gopalakrishnan, A., Basheer, V. S., Kushwaha, B., Sajeela. K. A. (2012): Development and characterization of a fibroblastic-like cell line from caudal fin of the red-line torpedo, Puntius denisonii (Day) (Teleostei: Cyprinidae). Aquacult Res, 43: 498-508.

Talwar, P. K., Jhingran, A. G. (1991): Inland Fishes of India and Adjacent Countries. Oxford and IBH Publishing Co, New Delhi.

Tan, F., Wang, M., Wang, W., Aguirre, A. A., Lu, Y. (2010): Validation of an in vitro cytotoxicity test for four heavy metals using cell lines derived from a green sea turtle (Chelonia mydas). Cell Biol Toxicol, 26, 255-263.

Tchounwou, P. B., Yedjou, C. G., Patlolla, A. K., Sutton, D. J. (2012): Heavy metal toxicity and the environment. In Molecular, clinical and environmental toxicology. Springer, Basel 133-164.

Tong, J., Wang, Y., Lu, Y. (2016): In vitro evaluation of inorganic and methyl mercury mediated cytotoxic effect on neural cells derived from different animal species. J Environ Sci, 41, 138-145.

Tong, S. L., Lee, H., Miao, H. Z. (1997): The establishment and partial characterization of a continuous fish cell line FG-9307 from the gill of flounder Paralichthys olivaceus. Aquac, 156, 327-333. 
Croatian Journal of Fisheries, 2021, 79, 15-24

M. S. Kumar et al. (2021): Caudal fin cell line of Barilius bendelisis

Vishwanath, W. (2010): Barilius bendelisis. The IUCN Red List of Threatened Species 2010:e.T166594A6243552. Retrieved from http:// dx.doi.org/10.2305/IUCN.

Ward, R. D., Zemlak, T. S., Innes, B. H., Last, P. R., Hebert, P. D. N. (2005): DNA barcoding Australia's fish species. UK.2010-4.RLTS. T166594A6243552.en. 